\title{
Colorectal cancer detection by measuring DNA from exfoliated colonocytes obtained by direct contact with rectal mucosa
}

\author{
ALEXANDRE LOKTIONOV ${ }^{1}$, TATIANA BANDALETOVA ${ }^{1}$, ANDREW H. LLEWELYN ${ }^{1}$, \\ CARINE DION $^{1}$, HUGO G.G. LYWOOD ${ }^{1}$, RUPERT C.G. LYWOOD ${ }^{1}$, TIM A. ROCKALL ${ }^{2}$, \\ JOHN F. STEBBING ${ }^{2}$, MARY BROUGHTON ${ }^{2}$, SUE CAFFAREY ${ }^{2}$ and CHRISTOPHER G. MARKS ${ }^{2}$ \\ ${ }^{1}$ Colonix Medical Limited, Cambridge CB22 3AT; ${ }^{2}$ Royal Surrey County Hospital, Guildford GU2 7XX, UK
}

Received September 5, 2008; Accepted October 22, 2008

DOI: 10.3892/ijo_00000152

\begin{abstract}
The purpose of the study was to explore the potential of direct exfoliated colonocyte collection from human rectal mucosa for colorectal cancer screening. A special device was designed for standardized collection of exfoliated cells from the surface of human rectal mucosa. Material was collected from 120 outpatients selected for colonoscopy and 36 patients with confirmed diagnosis of colorectal cancer or large polyps. Determination of total DNA amounts in the collected samples (DNA scores) by PicoGreen assay and real-time PCR was employed alongside cytological assessment. Well preserved cells with cytological patterns characteristic for different colorectal conditions (cancer, inflammatory bowel disease) were detected in the collected material. In the outpatient group DNA scores were higher in patients with cancer and inflammatory bowel disease compared to those with no abnormalities detected, diverticular disease and small polyps $(\mathrm{P}<0.001$ for PicoGreen assay; $\mathrm{P}=0.002$ for real-time $\mathrm{PCR}$ ). The sensitivity and specificity of the quantitative DNA test (PicoGreen assay; cut-off point $3.0 \mu \mathrm{g} / \mathrm{ml}$ ) for detecting serious colorectal conditions were 1.00 and 0.74 , respectively. In the group with confirmed tumours, the PicoGreen assay performed better for distal colorectal cancer (sensitivity 0.83 ; specificity 0.76 ) compared with proximal colon malignancies (sensitivity 0.57 ; specificity 0.76 ). It can be concluded that the proposed technique of direct collection of exfoliated cells from the surface of human rectal mucosa provides abundant cellular material suitable for diagnostic and research applications. Further refinement of the quantitative DNA test may lead to a new approach for colorectal cancer early detection and screening.
\end{abstract}

Correspondence to: Dr Alexandre Loktionov, Colonix Medical Ltd., Babraham Research Campus, Cambridge CB22 3AT, UK E-mail: alex.loktionov@colonixltd.co.uk

Key words: colon cancer, screening, exfoliated colonocyte collection, DNA quantification

\section{Introduction}

Colorectal cancer (CRC) is the second most prevalent malignancy worldwide, being the second commonest cause of cancer-related death (1). The benefits of CRC screening are generally recognized (1-6) and two categories of screening approaches are defined in the latest US CRC screening guidelines (1). The first category includes faecal tests such as faecal occult blood test (FOBT), faecal immunochemical test (FIT) and stool DNA analysis. Full or partial structural exams assigned to the second category comprise colonoscopy, flexible sigmoidoscopy (FS) and imaging techniques including computed tomographic colonography (CTC) and double contrast barium enema (DCBE). Nevertheless, all positive findings on faecal tests, DCBE, CTC and FS require confirmatory colonoscopy (1), which remains the key element of CRC diagnosis. Being a reliable diagnostic procedure, colonoscopy is, however, invasive and expensive. It also entails the cumulative risk of complications, especially if repeatedly performed for screening purposes (4). None of the mentioned pre-colonoscopy methods combines low invasiveness, simplicity and affordable cost with high sensitivity and specificity; therefore unnecessary colonoscopies remain common and the overall efficiency of CRC screening needs to be improved.

Non-invasive FOBT and FIT detect occult colonic bleeding $(7,8)$, but blood presence in faeces is not necessarily associated with neoplasia. The new group of faecal tests, employing the molecular analysis of DNA from exfoliated colonocytes excreted with stool $(9,10)$, is hampered by the absence of a single CRC-specific molecular trait. This necessitates the use of multiple complementary genetic markers $(4,9,11-16)$ making the approach technically demanding and expensive (17-19). Furthermore, purification of high quality human DNA from faeces is challenging $(13,14)$ and normal squamous epithelium of the anal canal shed during the act of defaecation contributes to the yield of DNA isolated from stool (20), thus decreasing cancer detection efficiency.

Exfoliated colonocytes could be far more useful for diagnostic and research applications if obtained without heavy faecal contamination (20). It is established that cell exfoliation from colorectal tumours is increased compared to normal mucosa $(9,20-23)$. Following exfoliation, colonocytes enter the 
mucocellular layer separating colonic epithelium from the gut contents $(20,23)$. It was hypothesized that this layer moves in parallel to the flow of faeces down to the rectum, leading to the buildup of the exfoliated cells on the surface of the rectal mucosa (20). Then in CRC patients exfoliated malignant cells, which are better adapted to autonomous existence (24-26), should be accumulated in the rectum, creating quantitative differences between cancer patients and healthy individuals. Similar changes are likely to be present in cases of chronic inflammatory conditions, which are known to be associated with an increased CRC risk and also require colonoscopy for diagnosis confirmation (27).

In order to test the hypothesis we have developed a technique for direct standardized collection of exfoliated cells from the rectum (28). This pilot study was undertaken with the purpose of assessing the potential of the new technique for colorectal disease detection and CRC screening.

\section{Materials and methods}

Study design. The study included the following stages: a) Hypothesis testing by collecting exfoliated cells from colon segments resected from CRC patients and tumour-free individuals. b) Development of laboratory techniques for assessing collected material. c) Development of a device for exfoliated cell collection from the surface of human rectal mucosa and setting-up a standardized cell collection procedure. d) Testing the approach in a pilot clinical trial including prospective blinded analysis of a group of symptomatic patients with unknown diagnosis and analysis of an additional group of patients with known CRC diagnosis for assessing possible tumour site effect.

The study protocol was approved by South West Surrey Local Research Ethics Committee. All patients gave written informed consent to the study protocol. The trial was registered in the International Standard Randomised Controlled Trial Number Register as ISRCTN30255103.

\section{Patients and sample collection}

Patients. All patients participating in the study were recruited at the Royal Surrey County Hospital (Guildford, UK). At the initial stage 20 resected colon specimens were analysed. CRC was confirmed in 18 cases (see results for details). No residual malignancy was found in two specimens resected following endoscopic removal of malignant polyps.

A total of 156 patients participated in the pilot trial (Table I). The main group analysed prospectively included 120 consecutive patients with colorectal complaints attending outpatient clinics and referred for colonoscopy. They did not have bowel preparation before sample collection. In 67 of these patients cell collection was repeated immediately before colonoscopy, following bowel preparation with Picolax.

There was also an additional group including 36 patients with CRC diagnosis. Samples from these patients were collected before operations, without bowel preparation.

Sample collection from resected colon segments. Resected colon segments were opened by a cut along anti-mesenteric surface. Exfoliated cells were collected by a gentle contact of a fixed area of inflatable elastic membrane with the surface of

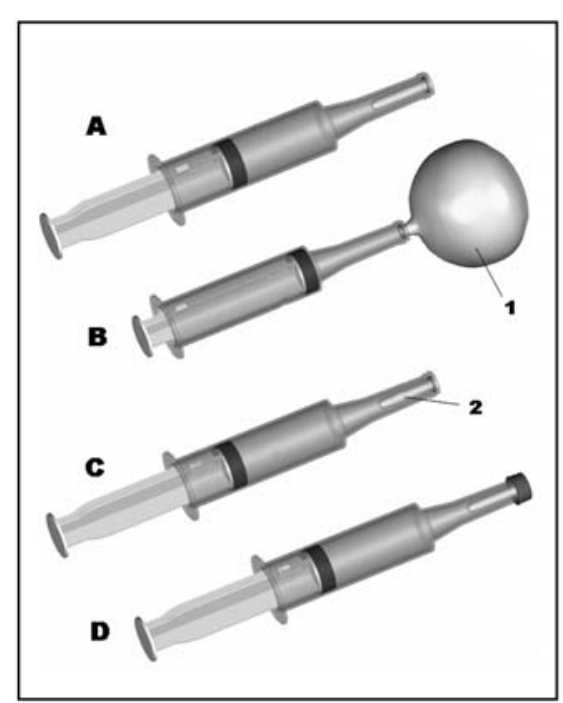

Figure 1. Device for direct cell collection from the surface of rectal mucosa. (A) Initial state; (B) plunger pushed, elastic nitrile membrane (1) inflated (cell collection state); (C) plunger pulled back, membrane retracted inside the device, cell lysis buffer added (2) and (D) device hermetically closed and ready for shipment to the laboratory.

tumours and unchanged mucosa at $5-7 \mathrm{~cm}$ proximally and distally from tumour margin.

Sample collection from outpatients and CRC patients. A device for standardized exfoliated cell collection from the surface of the rectal mucosa (Fig. 1) was designed (28) and manufactured by Colonix Medical Ltd. Before sample collection, patients underwent routine digital rectal examination. In order to collect cells, the balloon-holding end of the device was introduced through a proctoscope into the rectum. Inflation of the balloon with a fixed air volume brought the cell-collecting membrane into contact with the rectal mucosa to collect exfoliated cells from its surface. Following ten second inflation the membrane with collected material was retracted into the device, which was then removed from the proctoscope. All samples were collected by clinicians during patient examination. All problems associated with the procedure were recorded in coded individual protocols. Small fractions $(<5 \%)$ of the collected material were used for preparing smears on microscope slides for cytological examination. The remaining material was lysed in $5 \mathrm{ml}$ of cell lysis buffer (22) and sent to the laboratory of Colonix Medical Ltd together with the slides and the protocols.

Laboratory analyses. All analyses were blinded by withdrawing clinical information until completion of laboratory tests.

Cytological examination. Cell smears were stained with haematoxylin and eosin and examined microscopically. Individual smear descriptions were given. Microphotographs were taken with DP71 digital camera (Olympus Corporation, Japan).

Faecal contamination assessment. Faecal contamination was assessed by measuring optical absorbance of $100 \mu 1$ of each 
Table I. Characteristics of patients in the pilot clinical trial.

\begin{tabular}{|c|c|c|c|c|}
\hline \multirow[t]{3}{*}{ Variable } & \multicolumn{4}{|c|}{ Number of patients } \\
\hline & \multicolumn{2}{|c|}{ Outpatient study } & \multicolumn{2}{|c|}{ 'Known CRC' group } \\
\hline & Total 120 & Eligible $115^{\mathrm{a}}$ & Total 36 & Eligible $28^{b}$ \\
\hline \multicolumn{5}{|l|}{ Gender } \\
\hline Male & $48(40.0 \%)$ & $47(40.9 \%)$ & $25(69.4 \%)$ & $22(78.6 \%)$ \\
\hline Female & $72(60.0 \%)$ & $68(59.1 \%)$ & $11(30.6 \%)$ & $6(21.4 \%)$ \\
\hline \multicolumn{5}{|l|}{ Age } \\
\hline (Years, mean) & 66.0 & 65.7 & 73.2 & 73.9 \\
\hline (Years, CI 95\%) & $63.8-68.2$ & $64.5-66.8$ & $70.3-76.2$ & $70.8-77.0$ \\
\hline (Years, range) & $35-93$ & $35-93$ & $49-88$ & $44-88$ \\
\hline \multicolumn{5}{|l|}{ Sample contamination degree: } \\
\hline Low & $109(90.8 \%)$ & $104(90.4 \%)$ & $30(83.3 \%)$ & $22(78.6 \%)$ \\
\hline High & $11(9.2 \%)$ & $11(9.6 \%)$ & $6(17.7 \%)$ & $6(21.4 \%)$ \\
\hline \multicolumn{5}{|l|}{ Diagnosis: } \\
\hline No abnormalities detected (NAD) & & 52 & - & - \\
\hline Diverticular disease & & 29 & - & - \\
\hline Small polyps (<10 mm) & & 22 & - & - \\
\hline Large polyps ( $\geq 10 \mathrm{~mm})$ & & - & $2^{c}$ & $2^{\mathrm{c}}$ \\
\hline IBD (total) & & 7 & - & - \\
\hline IBD - Ulcerative colitis & & (4) & - & - \\
\hline IBD - Crohn's disease & & (2) & - & - \\
\hline IBD - Proctitis & & $(1)$ & - & - \\
\hline CRC (total) & & 4 & 34 & 26 \\
\hline CRC site - Cecum & & $(1)$ & (9) & (7) \\
\hline CRC site - ascending colon & & - & $(5)$ & $(5)$ \\
\hline CRC site - transverse colon & & - & (2) & (2) \\
\hline CRC site - descending colon & & - & (1) & - \\
\hline CRC site - sigmoid colon & & (2) & (6) & $(5)$ \\
\hline CRC site - rectum & & (1) & (12) & (7) \\
\hline \multicolumn{5}{|l|}{ CRC } \\
\hline Dukes' stage A & & 1 & 16 & 2 \\
\hline Dukes' stage B & & - & 18 & 16 \\
\hline Dukes' stage C & & 3 & 10 & 8 \\
\hline Other malignancies & & 1 stoma & - & - \\
\hline
\end{tabular}

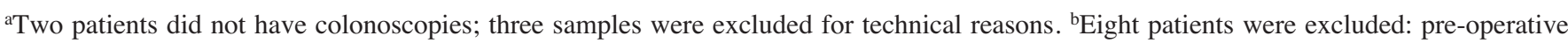
chemo- or radiotherapy, 5; complete intestinal obstruction, 1 and technical problems, 2. ${ }^{\mathrm{c}}$ One $30 \mathrm{~mm}$ tubulovillous adenoma in the ascending colon; one $25 \mathrm{~mm}$ tubulovillous adenoma in the sigmoid colon.

lysate at wavelength $340 \mathrm{~nm}$ using GENios fluorescent microplate reader (Tecan, Switzerland). Contamination degrees were defined as follows: $<1.5$, low or acceptable; $\geq 1.5$, high or unacceptable (values in optical absorbance units).

DNA isolation and quantification with PicoGreen. DNA was isolated from $120 \mu 1$ of cell lysate using QIAamp DNA mini kit (Qiagen, Germany), as previously described (22). DNA concentrations were measured using Invitrogen-i $\mathrm{T}^{\mathrm{TM}}$ PicoGreen ${ }^{\circledR}$ dsDNA assay kit (Invitrogen, USA) and GENios fluorescent microplate reader at wavelengths $485 \mathrm{~nm}$ (excitation) and $535 \mathrm{~nm}$ (emission) according to the instructions provided with the kit. The final value (DNA score) reflected DNA concentration $(\mu \mathrm{g} / \mathrm{ml})$ recalculated for the original lysate.

DNA quantification with real-time PCR (RT-PCR). Amplifiable human DNA in the samples was quantified by RT-PCR targeting a human-specific 71-bp fragment of the $\beta$-globin gene (exon 3$)$ with a previously reported $(29,30)$ set of PCR primers and TaqMan probe supplied by MWGBiotech (Germany): forward primer, 5'-GGGCAACGTGCT GGTCTG-3'; reverse primer, 5'-AGGCAGCCTGCACT GGT-3'; TaqMan probe, 5'-FAM-CTGGCCCATCACTTTG GCAAAGAA-BHQ-3' (FAM - 6-carboxyfluorescein; BHQ, Blackhole Quencher 1). 
The $15 \mu 1$ reactions included 1X QuantiFast Probe PCR master mix (Qiagen), both primers at $400 \mathrm{~nm}$, the TaqMan probe at $200 \mathrm{~nm}$ and $6 \mu 1$ of tested sample. Amplifications were performed using Mastercycler ep realplex (Eppendorf, Germany) with preincubation at $95^{\circ} \mathrm{C}$ for 3 min followed by 40 cycles of denaturation at $95^{\circ} \mathrm{C}$ for $3 \mathrm{sec}$ and annealing/ extension at $60^{\circ} \mathrm{C}$ for $30 \mathrm{sec}$. Amplifiable DNA concentrations were calculated by extrapolation from calibration curves generated by RT-PCR of fixed amounts of human genomic DNA. PCR template specificity controls included bovine and pig DNA (Novagen-Merck Chemicals, UK) and E. coli DNA (Sigma-Aldrich, UK). RT-PCR results were transformed into DNA scores by the realplex system software.

Data presentation and statistical analysis. The diagnosis in all patients was made on colonoscopy and confirmed at surgery by pathology reports when appropriate. Endoscopically removed polyps were classified according to histopathology, size and location. CRC cases were classified according to tumour location, histopathology and Dukes' stage. Tumours located below the splenic flexure (the descending colon, the sigmoid colon, the rectum) were classified as distal and all remaining tumours (the cecum, the ascending colon, the transverse colon) as proximal. In the initial part of the study (20 resections) the statistical analysis included descriptive statistics of DNA scores (means, confidence intervals, t-tests) for material taken proximally from tumours, from tumour surface and distally from tumours, or from normal mucosa of tumour-free specimens.

In the outpatient study, mean DNA scores and 95\% confidence intervals (CI-s) were calculated for groups defined by the final diagnosis (see Table I). The same approach with addition of t-test for paired observations was used for assessing bowel preparation effect. In order to establish the cut-off points for the quantitative DNA tests, receiver operating characteristic (ROC) curves were analyzed for the following situations: i) the outpatient study only, considering patients with 'serious colorectal disorders' including CRC, large polyps and IBD as 'positive' and all other cases as 'negative'; ii) pooled results of CRC cases from the outpatient study and known cancer group compared to patients with no abnormalities detected (NAD) from the outpatient group as surrogate 'controls'; iii) similar to ii, but with proximal and distal tumours analyzed separately. Sensitivity and specificity were assessed for different DNA score cut-off points. CI-s for sensitivity and specificity were calculated for proportions using the exact probabilities of the Binomial distribution (31). All statistical analyses were done using SPSS 14.0 software (SPSS Inc., USA).

\section{Results}

Hypothesis testing and development of laboratory procedures for the analysis of collected material

Cytological analysis. Massive cell exfoliation from tumours was observed in the specimens resected from CRC patients. Tumour tissue fragments, groups of tumour cells and numerous single cells were collected from both tumour surface and adjacent normal mucosa. In two cases mitoses were found in the exfoliated clusters of malignant cells. Neutrophils,

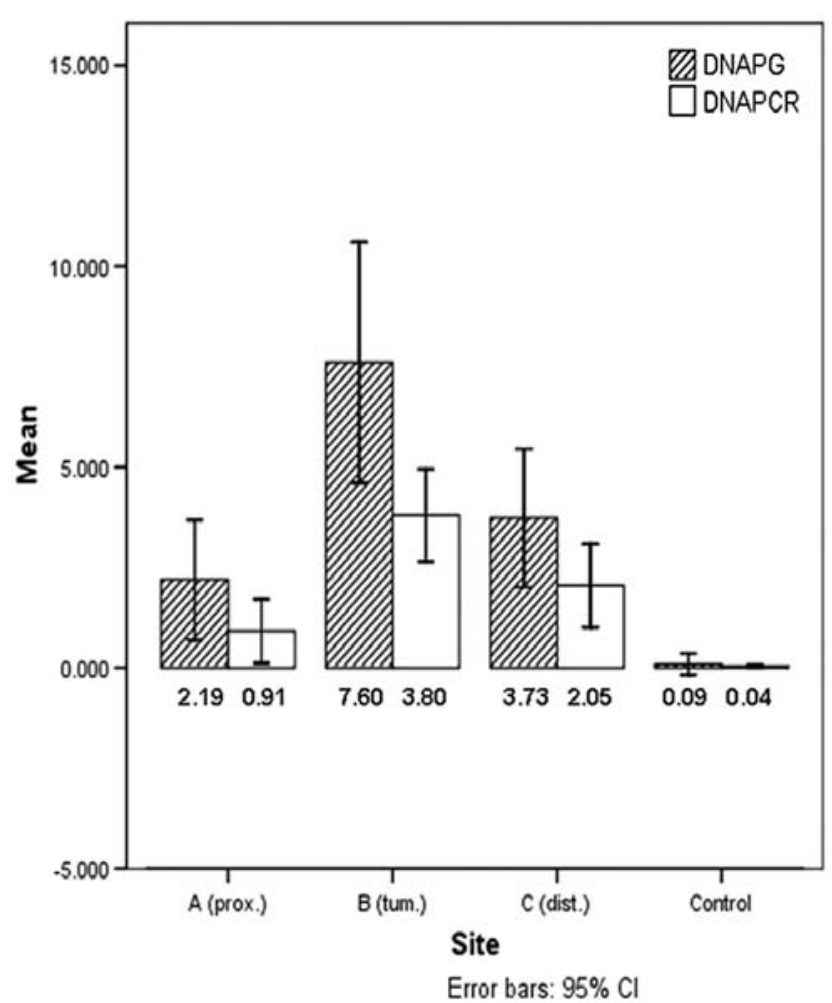

Figure 2. Mean DNA scores obtained for samples collected from the mucosal surface of colon specimens resected from CRC patients (A) proximally from the tumor; (B) from the tumor surface; (C) distally from the tumor and cancer-free controls (numbers under the bars indicate precise mean values).

lymphocytes and macrophages were commonly present, in addition to apoptotic bodies and cell debris.

In the material from the two tumour-free specimens cell numbers were considerably lower. Normal-looking single exfoliated colonocytes prevailed. Apoptotic cells were occasionally found.

Laboratory method development and DNA score assessment. The technique previously devised for isolating DNA from stool-derived exfoliated cells (22) was successfully applied in this study. As collected material was sometimes contaminated by faeces, co-isolation of interfering non-human DNA was not excluded. PicoGreen assay does not discriminate between human and non-human sequences, hence quantitative RT-PCR detecting only well preserved human DNA was applied as an alternative method. RT-PCR template specificity was confirmed by complete absence of amplification with three non-target templates.

Results of the DNA measurement by the two methods (Fig. 2) showed that the differences between very low DNA scores observed in the tumour-free specimens and high scores detected in CRC cases (all locations) were highly statistically significant. Within CRC case subgroup the mean PicoGreen and RT-PCR DNA scores for the samples collected from the tumour surface were higher than for those taken proximal to tumours $(\mathrm{P}=0.002$ and $\mathrm{P}<0.001$ respectively). Other comparisons did not show statistically significant differences, however DNA scores for the samples collected distally from tumours appeared to be generally higher than for those taken 
Table II. DNA scores ${ }^{a}$ obtained from material collected from resected colon specimens obtained from CRC patients and tumour-free patients (two resections following endoscopic removal of malignant polyps).

\begin{tabular}{|c|c|c|c|c|c|c|c|c|}
\hline \multirow[b]{3}{*}{ No. } & \multirow[b]{3}{*}{$\begin{array}{l}\text { Diagnosis } \\
\text { and site }\end{array}$} & \multicolumn{6}{|c|}{ Material collection site } & \multirow[b]{3}{*}{$\begin{array}{c}\text { Dukes' stage } \\
\text { and notes }\end{array}$} \\
\hline & & \multicolumn{3}{|c|}{ PicoGreen assay } & \multicolumn{3}{|c|}{ RT-PCR } & \\
\hline & & $\begin{array}{l}\text { Proximal } \\
\text { to tumour }\end{array}$ & $\begin{array}{l}\text { Tumour } \\
\text { surface }\end{array}$ & $\begin{array}{c}\text { Distal } \\
\text { to tumour }\end{array}$ & $\begin{array}{l}\text { Proximal } \\
\text { to tumour }\end{array}$ & $\begin{array}{l}\text { Tumour } \\
\text { surface }\end{array}$ & $\begin{array}{c}\text { Distal } \\
\text { to tumour }\end{array}$ & \\
\hline 1 & Ca sigmoid & 0.51 & 14.08 & 1.37 & 0.38 & 7.23 & 1.40 & $\begin{array}{l}\text { Dukes' A; } \\
\text { Mitoses detected }\end{array}$ \\
\hline 2 & Tumour-free & & $0.11^{\mathrm{b}}$ & & & $0.04^{\mathrm{b}}$ & & Taken as control \\
\hline 3 & Tumour-free & & $0.07^{\mathrm{b}}$ & & & $0.04^{\mathrm{b}}$ & & Taken as control \\
\hline 4 & Ca rectum & 7.02 & 15.44 & 9.33 & 2.01 & 7.30 & 6.11 & Dukes' B \\
\hline 5 & Ca sigmoid & 1.35 & 3.80 & 5.24 & 0.82 & 2.13 & 1.96 & Dukes' C1 \\
\hline 6 & Ca caecum & - & 5.54 & 0.43 & - & 3.29 & 0.36 & $\begin{array}{l}\text { Dukes' C2; } \\
\text { No proximal segment }\end{array}$ \\
\hline 7 & $\begin{array}{l}\text { Ca transverse } \\
\text { colon }\end{array}$ & 1.08 & 11.55 & 5.61 & 0.18 & 4.72 & 0.84 & $\begin{array}{l}\text { Dukes' C1; } \\
\text { Faecal contamination }\end{array}$ \\
\hline 8 & Ca rectum & 0.45 & 5.48 & 0.54 & 0.23 & 3.18 & 0.44 & Dukes' A \\
\hline 9 & Ca rectum & 0.31 & 9.35 & 11.18 & 0.28 & 6.55 & 6.76 & Dukes' B \\
\hline 10 & Ca rectum & 3.83 & 25.12 & 6.03 & 0.40 & 8.86 & 3.12 & $\begin{array}{l}\text { Dukes' C1; } \\
\text { Mitoses detected }\end{array}$ \\
\hline 11 & Ca rectum & 4.53 & 5.12 & 2.24 & 1.62 & 3.32 & 1.60 & $\begin{array}{l}\text { Dukes' } \mathrm{C} 1 \\
\text { Obstruction }\end{array}$ \\
\hline 12 & Ca rectum & 0.97 & 1.43 & - & 0.49 & 1.09 & - & $\begin{array}{l}\text { Dukes' A } \\
\text { No distal segment }\end{array}$ \\
\hline 13 & Ca sigmoid & 0.07 & 5.36 & 0.33 & 0.03 & 3.56 & 0.31 & Dukes' C2 \\
\hline 14 & Ca rectum & 0.29 & 2.29 & 3.23 & 0.01 & 1.33 & 1.85 & Dukes' C2 \\
\hline 15 & $\mathrm{Ca}$ rectum & 0.38 & 1.53 & 2.02 & 0.21 & 0.77 & 0.91 & Dukes' B \\
\hline 16 & $\begin{array}{l}\text { Ca transverse } \\
\text { colon }\end{array}$ & 0.85 & 4.44 & 1.31 & 0.17 & 2.70 & 0.50 & Dukes' C1 \\
\hline 17 & Ca rectum & 10.76 & 6.92 & 1.43 & 6.46 & 3.69 & 1.02 & $\begin{array}{l}\text { Dukes' C1; } \\
\text { Severe obstruction }\end{array}$ \\
\hline 18 & Ca rectum & 2.28 & 11.03 & 5.73 & 0.93 & 3.89 & 3.55 & Dukes' B \\
\hline 19 & Ca rectum & 0.09 & 2.22 & - & 0.03 & 1.59 & - & $\begin{array}{l}\text { Dukes' B; } \\
\text { No distal segment }\end{array}$ \\
\hline 20 & Ca rectum & 2.45 & 6.18 & 3.56 & 1.23 & 3.12 & 2.01 & Dukes' B \\
\hline
\end{tabular}

aDue to differences in material collection procedures DNA scores obtained in this part of the study should not be directly compared to those obtained in the pilot clinical trial. ${ }^{b}$ Average from three samples collected within each tumour-free specimen. Ca, carcinoma.

proximally with only two cases of obstructing rectal cancer demonstrating higher DNA scores proximally from tumours (Table II, \#11 and \#17). Although RT-PCR provided lower DNA scores compared to those generated by the PicoGreen assay, the patterns of the results were remarkably similar (Fig. 2). Individual results are given in Table II.

Development of the device and procedure for direct exfoliated cell collection from the surface of human rectal mucosa. The device developed for the exfoliated cell collection from the surface of rectal mucosa is shown in Fig. 1. Cell collection procedure was comparable to proctoscopy in terms of simplicity and low invasiveness. No complications were observed during 223 sample collections in 156 patients.

Only five samples had to be excluded because of either material collection failure (one) or material handling errors (four). 
Table III. DNA scores measured by PicoGreen assay (PG) and real-time PCR (RT-PCR) in 115 eligible outpatients without bowel preparation and in 67 of them for the second time, after bowel preparation with Picolax.

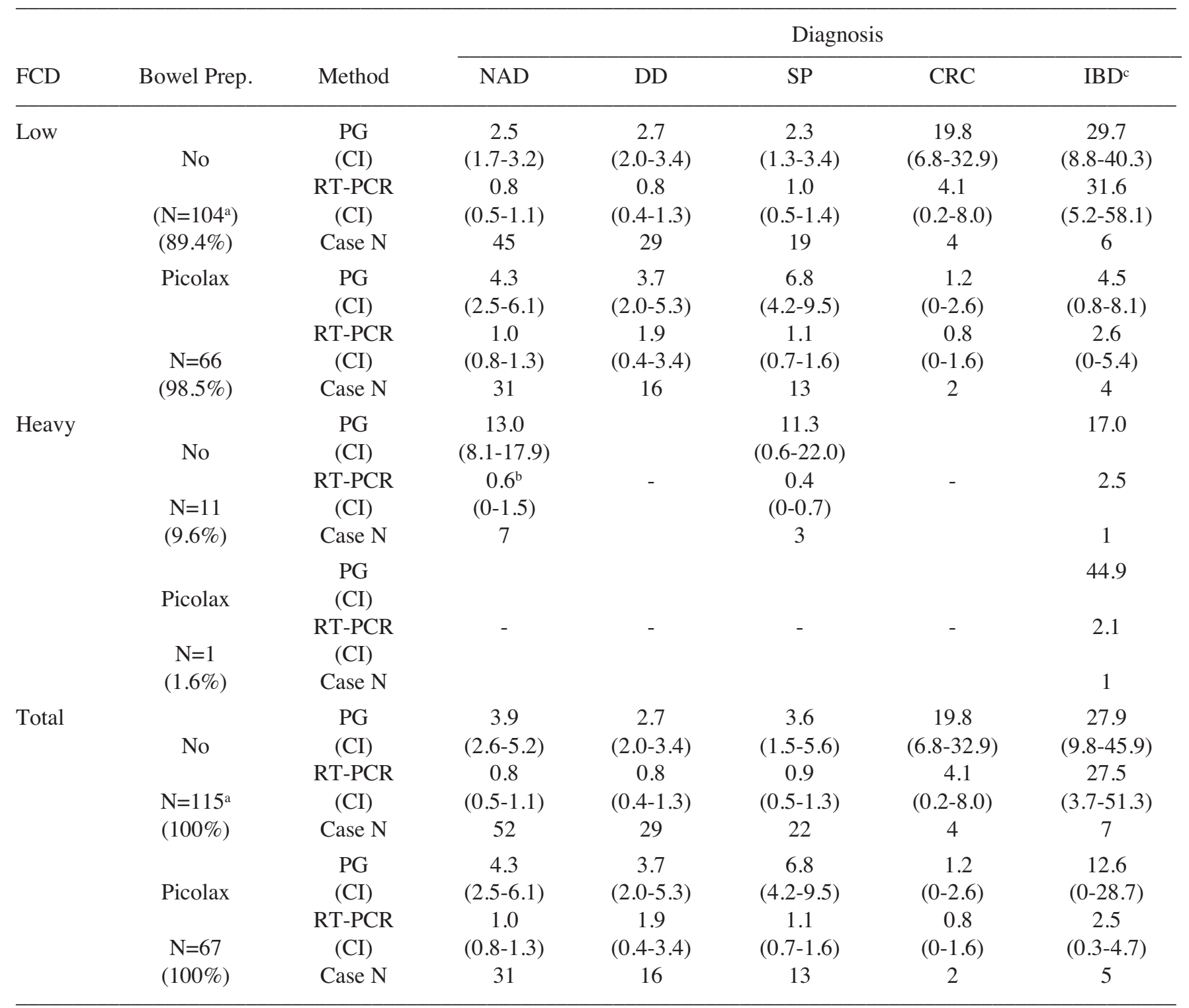

FCD, fecal contamination degree; NAD, no abnormalities detected; DD, diverticular disease; SP, small polyps; CRC, colorectal cancer; IBD,

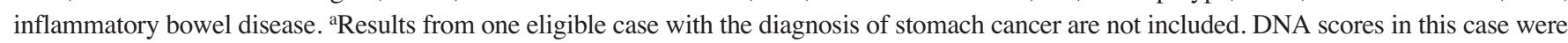

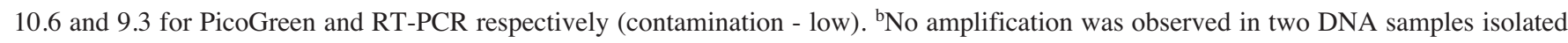
from heavily contaminated material. 'The IBD group included four cases of ulcerative colitis, two cases of Crohn's disease and one case of proctitis (see Fig. 3).

Faecal contamination. Although 205 (91.9\%) of 223 collected samples had low or no faecal presence, $18(8.1 \%)$ were heavily contaminated. Heavy contamination compromised quantitative assays resulting in very high PicoGreen DNA scores, but mostly low DNA scores in the same samples when measured by RT-PCR. All quantitative results are shown in Tables III and IV and Fig. 3, but cases with heavy contamination were excluded when sensitivity and specificity of the test were analyzed.

Outpatient study. Among 120 outpatients who provided samples 115 were eligible for further analysis (Table I). The final diagnoses of the eligible outpatients are shown in Table I and Fig. 3.

Cytological examination. Smears from patients with NAD contained relatively few single normal colonocytes (Fig. 4a), occasional erythrocytes, neutrophils and squamous epithelial cells. Colonocyte groups and fragments of colonic epithelium were sometimes found, but the latter observation was mostly associated with diverticular disease (Fig. 4b). No clear cytological pattern was related to the presence of small polyps. Characteristic changes in patients with IBD, especially ulcerative colitis, included an abundance of neutrophils 
$\mathbf{A}$

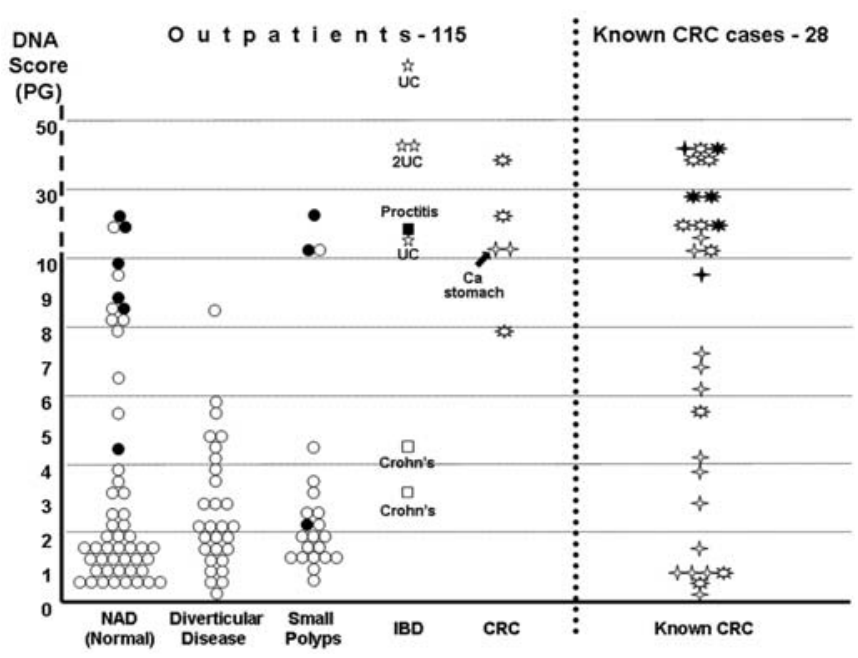

B

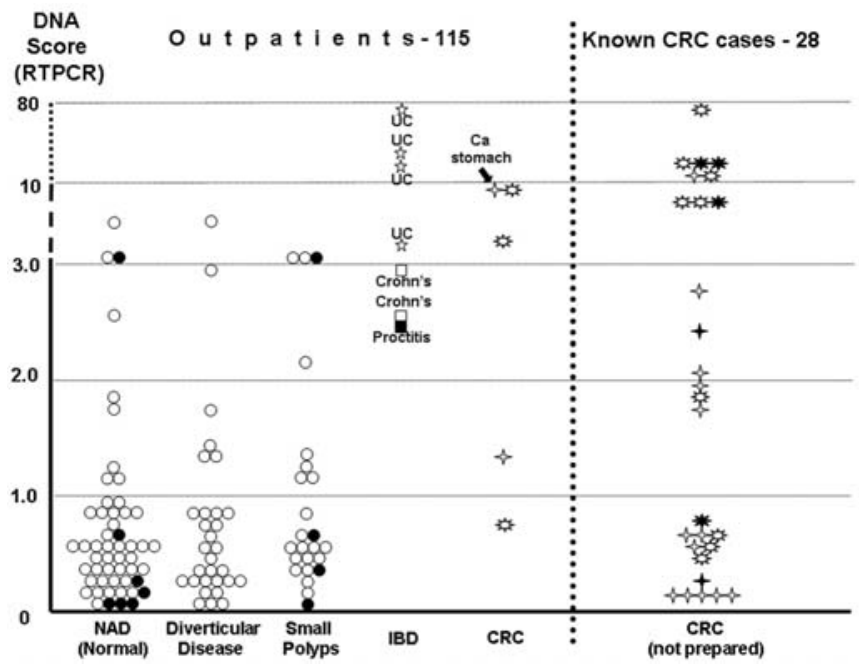

Figure 3. DNA score distribution determined by PicoGreen (A) and RT-PCR (B) assays. Results of the outpatient study are presented by diagnosis (115 eligible cases shown). Known cancer cases are presented according to bowel preparation status. Circles indicate individual results in patients with no abnormalities detected (NAD), diverticular disease; hyperplastic polyps and small adenomas; four-pointed stars, proximal cancer; eight-pointed stars, distal cancer; five-pointed stars, ulcerative colitis; squares, other inflammatory conditions. Colour of the symbols shows individual sample contamination degree (white, low; black, high).

$\mathbf{A}$

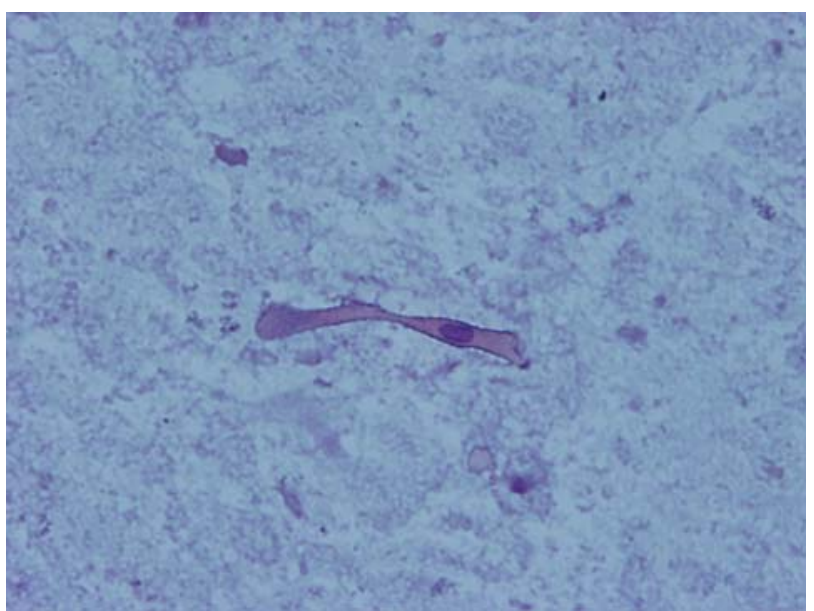

C

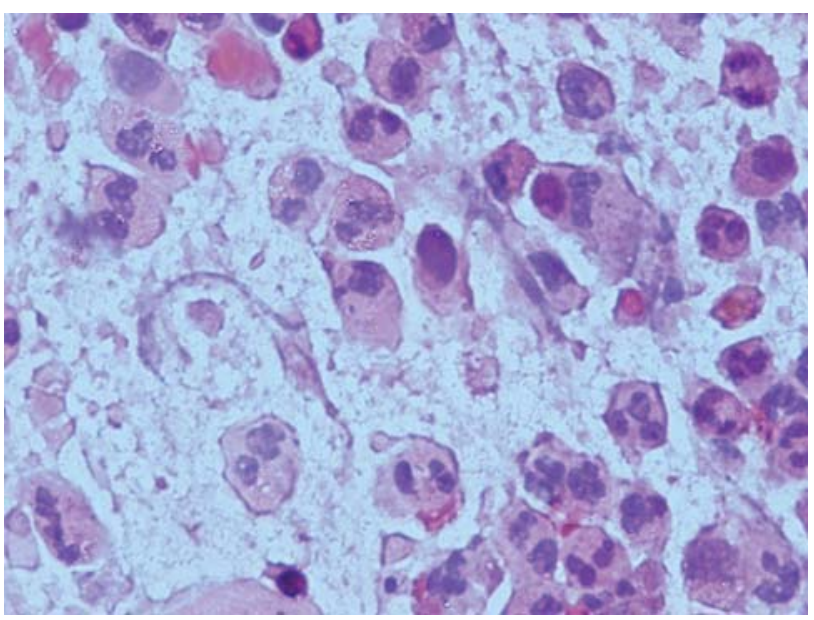

B

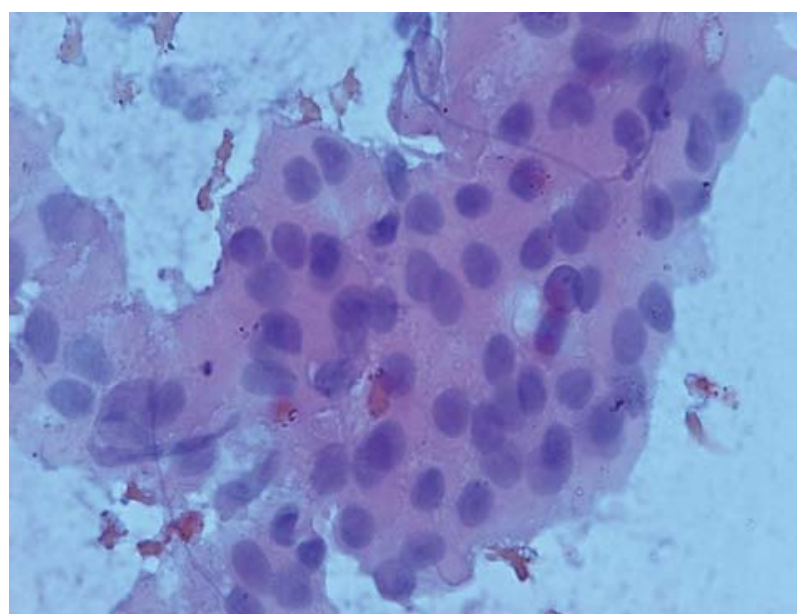

D

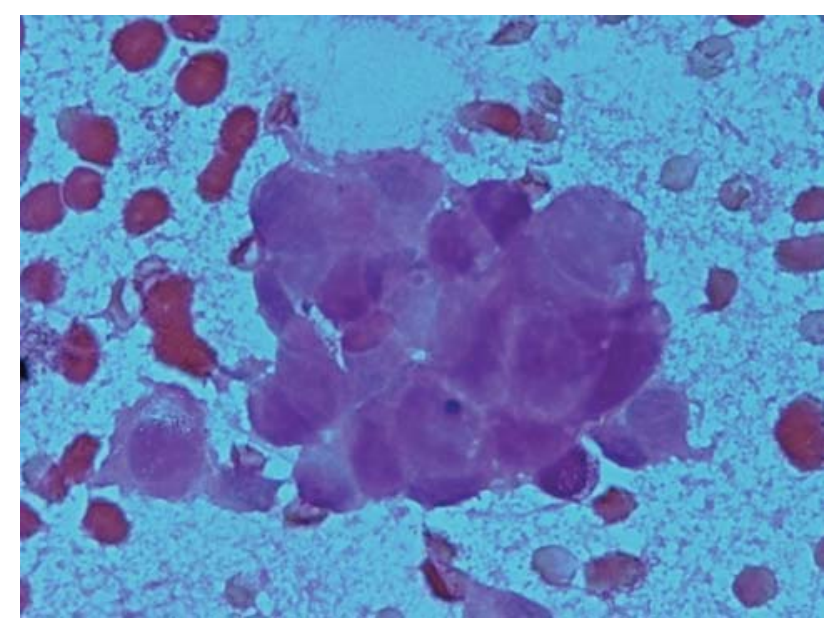

Figure 4. Examples of cells collected from the surface of human rectal mucosa: (A) Normal-looking single exfoliated colonocyte (note characteristically elongated shape of the cell). (B) Exfoliated fragment of normal-looking colonic epithelium. Such findings were especially common in patients with diverticular disease. (C) Abundance of neutrophils in material taken from a patient with ulcerative colitis. Several apoptotic bodies are also present. (D) Cluster of malignant cells from a patient with rectal cancer. Erythrocytes present around the cell cluster. 
Table IV. DNA scores measured by PicoGreen assay (PG) and real-time PCR (RT-PCR) in samples taken from 32 eligible CRC patients with colorectal tumours (30 CRC cases including four from the outpatient group and two large polyps). ${ }^{a}$

\begin{tabular}{lccccc}
\hline & & \multicolumn{3}{c}{ Diagnosis } \\
\cline { 3 - 5 } FCD & Method & CRC (all) & Proximal tumours & Distal tumours & No abnormalities detected (NAD) \\
\hline Low & PG & 12.1 & 5.5 & 19.7 & 2.5 \\
& & $(7.1-17.1)$ & $(2.8-8.2)$ & $(11.0-28.4)$ & $(1.7-3.2)$ \\
& RT-PCR & 6.8 & 1.8 & 12.7 & 0.8 \\
& & $(0.7-12.8)$ & $(0.1-3.4)$ & $(0.3-25.1)$ & $(0.5-1.1)$ \\
\multirow{4}{*}{ Heavy } & Case N & 26 & 14 & 12 & 45 \\
& PG & 28.0 & 25.7 & 29.1 & 13.0 \\
& & $(17.8-38.1)$ & $(0-57.4)$ & $(19.9-38.4)$ & 0.6 \\
& RT-PCR & 9.7 & 1.3 & 13.9 & $(0-1.5)$ \\
Total & & $(0.8-18.5)$ & $(0-3.4)$ & $(2.6-25.2)$ & 7 \\
& Case N & 6 & 2 & 4 & 3.9 \\
& PG & 15.1 & 8.0 & 22.1 & $(2.6-5.2)$ \\
& RT-PCR & $(10.1-20.0)$ & $(3.0-13.0)$ & $(15.0-29.2)$ & 0.8 \\
& & 7.3 & 1.7 & 13.0 & $(0.5-1.1)$ \\
& Case N & $(2.2-12.5)$ & $(0.3-3.2)$ & $(3.4-22.5)$ & 52
\end{tabular}

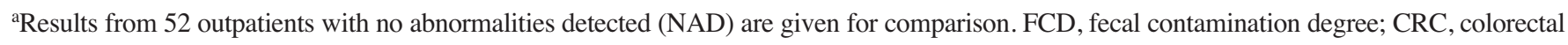
cancer and NAD, no abnormalities detected.

(Fig. 4c) and fresh blood. Lymphocytes and larger cells (probably monocytes/macrophages or dysplastic epithelial cells) were also observed as well as single colonocytes, apoptotic bodies and cell debris. Examination of material from CRC cases (comprising 'known CRC') revealed extreme abundance of apoptotic bodies and cell debris. Chronic bleeding signs, in particular fragments of organized thrombi, were common. Neutrophils and eosinophils were often observed. Easily identifiable malignant cells (Fig. 4d) were relatively rare, especially compared to the material from resected specimens described before.

DNA score assessment. Although CRC was diagnosed in only four outpatients, DNA scores determined by the both quantification methods showed higher values for the malignancies compared to all patients without serious pathology (Table III and Fig. 3). Interestingly, a very high DNA score was observed in one patient with gastric cancer (Fig. 3). The presence of IBD, especially ulcerative colitis, also increased DNA scores. Comparison of pooled results from CRC and IBD cases against pooled results from all remaining patients has shown a highly significant statistical difference $(\mathrm{P}=0.006$ for the PicoGreen assay; $\mathrm{P}=0.046$ for the RT-PCR assay for samples with low contamination) with the reservation that the number of eligible patients with serious conditions was small (4 CRC and 6 IBD). The ROC curve for sensitivity and specificity assessment of the test for detecting serious conditions is shown in Fig. 5 with sensitivity of $1.00(\mathrm{CI}=0.69-1.00)$ and specificity of 0.75 $(\mathrm{CI}=0.65-0.84)$ demonstrated for the PicoGreen test at DNA score cut-off point of $3.0 \mu \mathrm{g} / \mathrm{ml}$. The real-time PCR-based assay provided sensitivity of $0.90(\mathrm{CI}=0.55-1.00)$ and specificity of $0.86(\mathrm{CI}=0.77-0.92)$ at DNA score cut-off point of $1.25 \mu \mathrm{g} / \mathrm{ml}$.

Effect of bowel preparation on DNA score distribution. Although preparation with Picolax reduced the proportion of contaminated samples, DNA scores in individuals without serious colorectal conditions increased following bowel preparation (Table III). Paired t-test analysis of 52 pairs of samples (low contamination only) obtained from patients without serious colorectal conditions indicated an increase of both PicoGreen- and RT-PCR-measured DNA scores after bowel preparation ( $\mathrm{P}=0.004$ and $\mathrm{P}=0.068$, respectively).

In contrast, Picolax caused a decrease of DNA score values in six patients with $C R C$ and IBD $(\mathrm{P}=0.017$ and $\mathrm{P}=0.070$ for PicoGreen- and RT-PCR-measured DNA scores respectively, see also Table III). Therefore bowel preparation reduced the difference between DNA score values found in unprepared cancer and IBD patients when compared with those who did not have serious colorectal conditions.

DNA score determination in patients with confirmed CRC diagnosis. An additional group of 36 patients with a clinical CRC diagnosis were recruited to examine the ability of the test to detect tumours at different sites within the colon. Eight of these cases were excluded from the analysis for different reasons (Table I).

Table IV compares the results observed in CRC patients and outpatients with NAD. Although there was a wide variation in the cancer group, DNA scores were generally high. Patients with proximal tumours more often had lower DNA scores. This was most apparent when DNA was measured by RT-PCR. Nevertheless, 9 of 16 and 6 of 16 
Table V. Test sensitivity and specificity values for comparison of CRC cases (including four CRC cases from the outpatient group and two cases of large polyps) with patients with no abnormalities detected (NAD) from the outpatient group. ${ }^{\text {a }}$

\begin{tabular}{|c|c|c|c|c|}
\hline \multirow[b]{2}{*}{ Cut-off point } & \multicolumn{3}{|c|}{ Sensitivity } & \multirow[b]{2}{*}{ Specificity } \\
\hline & For all CRC cases & For proximal tumour cases & For distal tumour cases & \\
\hline \multicolumn{5}{|c|}{ PicoGreen Assay } \\
\hline 2.0 & $\begin{array}{c}0.73 \\
(0.52-0.88)\end{array}$ & $\begin{array}{c}0.64 \\
(0.35-0.87)\end{array}$ & $\begin{array}{c}0.83 \\
(0.52-0.98)\end{array}$ & $\begin{array}{c}0.64 \\
(0.49-0.78)\end{array}$ \\
\hline 3.0 & $\begin{array}{c}0.69 \\
(0.48-0.86)\end{array}$ & $\begin{array}{c}0.57 \\
(0.29-0.82)\end{array}$ & $\begin{array}{c}0.83 \\
(0.52-0.98)\end{array}$ & $\begin{array}{c}0.76 \\
(0.60-0.87)\end{array}$ \\
\hline 4.0 & $\begin{array}{c}0.65 \\
(0.44-0.83)\end{array}$ & $\begin{array}{c}0.50 \\
(0.23-0.77)\end{array}$ & $\begin{array}{c}0.83 \\
(0.52-0.98)\end{array}$ & $\begin{array}{c}0.84 \\
(0.71-0.94)\end{array}$ \\
\hline 5.0 & $\begin{array}{c}0.62 \\
(0.41-0.80)\end{array}$ & $\begin{array}{c}0.43 \\
(0.18-0.71)\end{array}$ & $\begin{array}{c}0.83 \\
(0.52-0.98)\end{array}$ & $\begin{array}{c}0.87 \\
(0.73-0.95)\end{array}$ \\
\hline $\begin{array}{l}\text { Area under } \\
\text { the ROC curve }\end{array}$ & $\begin{array}{c}0.75 \\
(0.62-0.88)\end{array}$ & $\begin{array}{c}0.66 \\
(0.48-0.85)\end{array}$ & $\begin{array}{c}0.85 \\
(0.69-1.00)\end{array}$ & \\
\hline \multicolumn{5}{|c|}{ RT-PCR assay } \\
\hline 0.75 & $\begin{array}{c}0.58 \\
(0.37-0.77)\end{array}$ & $\begin{array}{c}0.43 \\
(0.18-0.71)\end{array}$ & $\begin{array}{c}0.75 \\
(0.43-0.95)\end{array}$ & $\begin{array}{c}0.64 \\
(0.49-0.78)\end{array}$ \\
\hline 1.00 & $\begin{array}{c}0.54 \\
(0.33-0.73)\end{array}$ & $\begin{array}{c}0.43 \\
(0.18-0.71)\end{array}$ & $\begin{array}{c}0.67 \\
(0.35-0.90)\end{array}$ & $\begin{array}{c}0.82 \\
(0.68-0.92)\end{array}$ \\
\hline 1.25 & $\begin{array}{c}0.54 \\
(0.33-0.73)\end{array}$ & $\begin{array}{c}0.43 \\
(0.18-0.71)\end{array}$ & $\begin{array}{c}0.67 \\
(0.35-0.90)\end{array}$ & $\begin{array}{c}0.89 \\
(0.76-0.96)\end{array}$ \\
\hline 1.50 & $\begin{array}{c}0.54 \\
(0.33-0.73)\end{array}$ & $\begin{array}{c}0.43 \\
(0.18-0.71)\end{array}$ & $\begin{array}{c}0.67 \\
(0.35-0.90)\end{array}$ & $\begin{array}{c}0.89 \\
(0.76-0.96)\end{array}$ \\
\hline $\begin{array}{l}\text { Area under } \\
\text { the ROC curve }\end{array}$ & $\begin{array}{c}0.69 \\
(0.54-0.83)\end{array}$ & $\begin{array}{c}0.55 \\
(0.34-0.76)\end{array}$ & $\begin{array}{c}0.85 \\
(0.72-0.97)\end{array}$ & \\
\hline
\end{tabular}

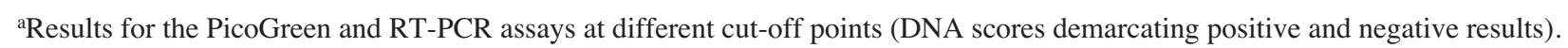

proximal tumours were associated with high DNA scores when measured by PicoGreen and RT-PCR assays, respectively. Two large tubulovillous adenomas (one proximal and one distal) were found in the eligible operated patients and both of them were associated with high DNA scores.

In order to establish a cut-off DNA score value for demarcating negative and positive results, tentative ROC curves were created by comparing results of all cancer patients including those detected in the outpatient group with outpatients with no abnormalities detected during colonoscopy (ROC curves are not shown). The test detected the presence of CRC with sensitivity and specificity values dependent on the selected cut-off point (Table V). Optimal cut-off point values were in the range of 2.5-4.0 $\mu \mathrm{g} / \mathrm{ml}$ for PicoGreen and 1.0-1.5 $\mu \mathrm{g} / \mathrm{ml}$ for RT-PCR. Sensitivity and specificity values for PicoGreen and RT-PCR assays for detecting any $\mathrm{CRC}$ were $0.69(\mathrm{CI}=0.48-0.86)$ and 0.76 $(\mathrm{CI}=0.60-0.87)$ and $0.54(\mathrm{CI}=0.33-0.73)$ and $0.89(\mathrm{CI}=$ $0.76-0.96)$ at DNA score cut-off points of $3.0 \mu \mathrm{g} / \mathrm{ml}$ and $1.25 \mu \mathrm{g} / \mathrm{ml}$, respectively. Separate analysis of proximal and distal cancer cases showed that the test better detected distal
CRC compared to proximal tumours (see Table V). DNA scores were not affected by the Dukes' stage or histopathology of analysed CRC cases.

\section{Discussion}

We have described a simple, minimally invasive approach for the collection of cells from the surface of human rectal mucosa in a standardized way. Although the idea of measuring the amount of DNA extracted from stool-derived exfoliated colonocytes for diagnostic purposes has previously been discussed $(22,29)$, quantification of DNA isolated from material collected directly from the surface of rectal mucosa can be regarded as a new concept.

The amount and quality of cells obtained by the new method were by far superior compared to any existing stool-based technique (20). Cytological examination of the samples has shown disease-specific patterns and has demonstrated the availability of well preserved cells that can be successfully analyzed by various molecular approaches (9-11). 
$\mathbf{A}$

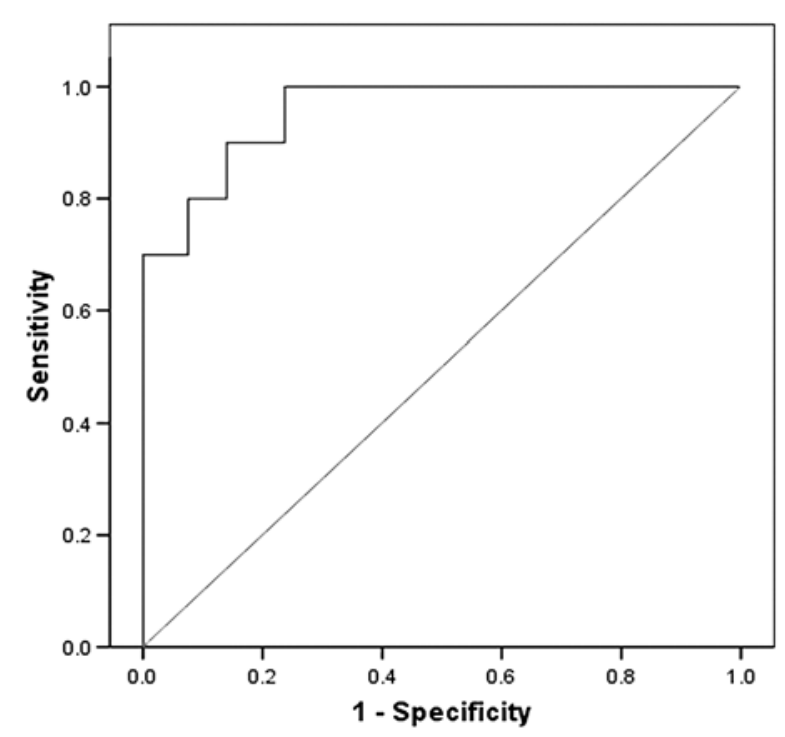

B

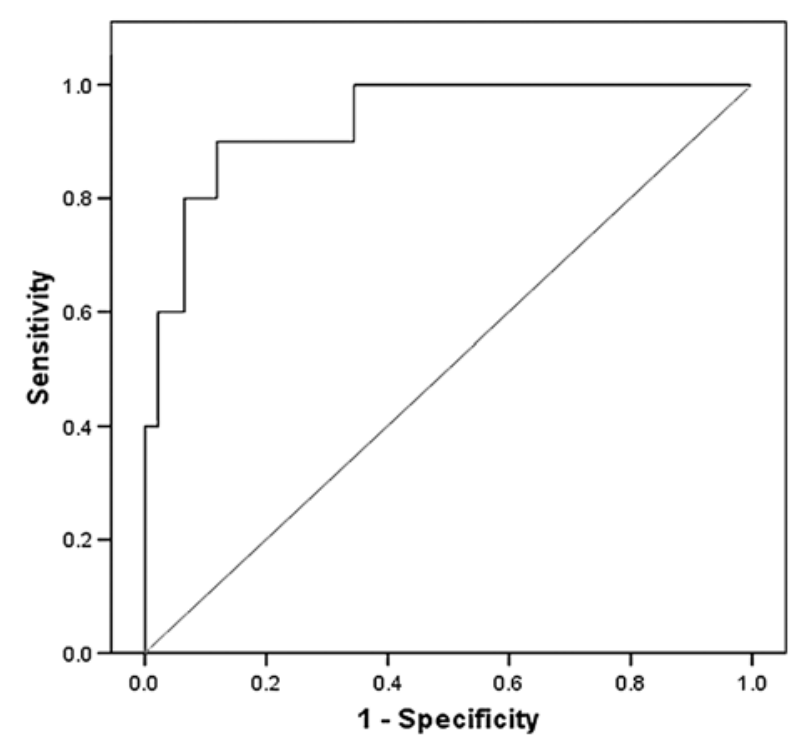

Figure 5. ROC curves describing sensitivity and specificity of detection of 'serious colorectal conditions' by PicoGreen (A) and real-time PCR (B) DNA score assessment in the prospective outpatient trial. Comparison of 10 cases of 'serious conditions' (CRC, ulcerative colitis, Crohn's disease) against 93 patients with any other conditions (NAD, diverticular disease, small polyps). Samples with heavy faecal contamination are excluded. For the PicoGreen assay (A) sensitivity and specificity were $1.00(\mathrm{CI}=0.69-1.00)$ and $0.59(\mathrm{CI}=0.48-0.69) ; 1.00(\mathrm{CI}=0.69-1.00)$ and $0.75(\mathrm{CI}=0.65-0.84) ; 0.90(\mathrm{CI}=0.55-1.00)$ and $0.83(\mathrm{CI}=0.74-0.90) ; 0.80(\mathrm{CI}=0.44-0.97)$ and $0.88(\mathrm{CI}=0.80-0.94)$; for DNA score cut-off points of 2.0,3.0,4.0 and 5.0 respectively. Area under the curve $=0.955(0.90-1.00)$. For the real-time PCR assay $(\mathrm{B})$ sensitivity and specificity were $1.00(\mathrm{CI}=0.69-1.00)$ and $0.66(\mathrm{CI}=0.55-0.75)$; 0.90 $(\mathrm{CI}=0.55-1.00)$ and $0.80(\mathrm{CI}=0.70-0.87) ; 0.90(\mathrm{CI}=0.55-1.00)$ and $0.86(\mathrm{CI}=0.77-0.92) ; 0.80(\mathrm{CI}=0.44-0.97)$ and $0.89(\mathrm{CI}=0.81-0.95)$; for DNA score cut-off points of 0.75 , $1.0,1.25$ and 1.5, respectively. Area under the curve $=0.94(0.87-1.00)$.

The goal of this study was to assess the applicability of simple measurement of total DNA isolated from samples collected from the surface of rectal mucosa as an indicator of the presence of serious colorectal conditions. Our prospective blinded outpatient study has highlighted the difference between high DNA scores in patients with CRC and chronic inflammatory bowel conditions and low scores in symptomatic patients with normal colons or less serious conditions. This finding may offer an efficient way for avoiding unnecessary colonoscopies.

It also appears that different cell types present in the mucocellular layer are responsible for DNA score increase in CRC and IBD. Cytological analysis has shown that in IBD patients massive presence of neutrophils was the main DNA source, whereas material exfoliated from tumour surface generated DNA abundance in cancer patients.

In some patients, faecal presence in the rectum prevented adequate contact of the collecting membrane with the rectal mucosa. Contaminated samples contained large amounts of bacterial DNA, producing high scores in the PicoGreen assay. RT-PCR in most of these cases was inhibited by faeces-derived substances co-isolated with DNA $(32,33)$, but it should be noted that, despite the inhibitory effect, DNA scores detected by this method remained very high in a few cases of distal CRC (see Fig. 3b). Although reduction of contamination might improve the performance of the test, bowel preparation was not suitable for this purpose because Picolax decreased the discriminatory power of the test.

At the last stage of the study material was collected from a group of patients with confirmed CRC and large adenomatous polyps. Whereas DNA scores were high in the majority of cases, results below 2.0 (PicoGreen assay) were observed in seven unprepared CRC patients. It is important to note that five of these patients had varying degrees of intestinal obstruction, which could interfere with the normal movement of the mucocellular layer where exfoliated cells are found. This suggestion is supported by the findings in the initial pilot study of resected specimens, when two patients with signs of intestinal obstruction (Table II, \#11 and \#17) displayed an unusual distribution of the exfoliated material with higher DNA scores obtained for the mucosal surface proximally from the tumour.

The ultimate objective of this study was to develop a novel means of CRC screening. Distal colon tumours appeared to be easy to detect using the both DNA measurement techniques. The test was less efficient for detecting cancers of the proximal colon, but ROC curve analysis still demonstrated encouraging sensitivity and specificity values for these tumours rarely detected by FOBT (34). PicoGreen assay was more efficient than real-time PCR in detecting proximal cancers (see Fig. 3 and Tables IV and V). A possible explanation of the difference is the detection by the PicoGreen assay of a higher proportion of finely fragmented double-stranded human DNA generated from cells undergoing apoptosis during long migration of the exfoliated material through the colon within its mucocellular layer. This explanation, however, remains hypothetical and needs confirmation. Sensitivity and specificity results for the detection of CRC regardless site within the colon should be taken with caution since the proportion of proximal tumours in this study was unusually high.

It is obvious that the simple quantitative assay described in this study can be supplemented by additional qualitative 
methods already developed for stool analysis (11-16). Given high quality of directly collected exfoliated material, application of qualitative molecular methods in combination with our approach is likely to result in further improvement of CRC screening efficiency.

In summary, a technique based on the measurement of the amount of DNA isolated from exfoliated material collected from the surface of the rectal mucosa has been developed as a simple screening test for colorectal disease. High DNA scores clearly correlated with the presence of colorectal cancer and inflammatory bowel disease, indicating that the test can also be used in symptomatic patients for identifying cases requiring urgent attention.

The results of this small pilot study are highly encouraging. Larger clinical trials are needed in order to provide an appropriate assessment of the validity of the new test.

\section{Acknowledgements}

We are indebted to Professor M. Cook and Drs S. de Sanctis, S. di Palma, M. Green and P. Jackson from the Department of Pathology of the Royal Surrey County Hospital for their help in sample collection and provision of diagnostic pathology results. This study was partially supported by a Grant for Research and Development awarded by EEDA (East of England Development Agency). All co-authors of this paper affiliated to Colonix Medical Limited (AL, TB, AHL, CD, HGG, RCG) may have a potential financial conflict of interests because of being associated with a private company.

\section{References}

1. Levin B, Lieberman DA, McFarland B, et al: Screening and surveillance for the early detection of colorectal cancer and adenomatous polyps, 2008: A joint guideline from the American Cancer Society, the US Multi-Society Task Force on Colorectal Cancer, and the American College of Radiology. Gastroentorology 134: 1570-1595, 2008

2. Walsh JM and Terdiman JP: Colorectal cancer screening: scientific review. JAMA 289: 1288-1296, 2003

3. Walsh JM and Terdiman JP: Colorectal cancer screening: clinical applications. JAMA 289: 1297-1302, 2003.

4. Ransohoff D: Colon cancer screening in 2005: Status and challenges. Gastroenterology 128: 1685-1695, 2005.

5. Smith RA, Cokkinides V and Eyre HJ: American Cancer Society guidelines for the early detection of cancer, 2006. CA Cancer J Clin 56: 11-25, 2006.

6. Toppenden P, Chilcott J, Eggington S, Patnick J, Sakai H and Karnon J: Option appraisal of population-based colorectal cancer screening programmes in England. Gut 56: 677-684, 2007.

7. Burch JA, Soares-Weiser K, St John DJ, Duffy S, Smith S Kleijnen J and Westwood M: Diagnostic accuracy of faecal occult blood tests used in screening for colorectal cancer: a systematic review. J Med Screen 14: 132-137, 2007.

8. Allison JE, Sakoda LC, Levin TR, et al: Screening for colorectal neoplasms with new fecal occult blood tests: update on performance characteristics. J Natl Cancer Inst 99: 1462-1470, 2007.

9. Osborn NK and Ahlquist DA: Stool screening for colorectal cancer: Molecular approaches. Gastroenterology 128: 192-206, 2005.

10. Davies RJ, Miller R and Coleman N: Colorectal cancer screening: Prospects for molecular stool analysis. Nat Rev Cancer 5: 199-209, 2005

11. Ahlquist DA, Skoletsky JE, Boynton KA, Harrington JJ, Mahoney DW, Pierceall WE, Thibodeau SN and Shuber AP: Colorectal cancer screening by detection of altered human DNA in stool: feasibility of a multitarget assay panel. Gastroenterology 119: 1219-1227, 2000
12. Dong SM, Traverso G, Johnson C, et al: Detecting colorectal cancer with the use of multiple genetic targets. J Natl Cancer Inst 93: 858-865, 2001.

13. Traverso G, Shuber A, Levin B, et al: Detection of APC mutations in fecal DNA from patients with colorectal tumors. N Engl J Med 346: 311-320, 2002 .

14. Tagore KS, Lawson MJ, Yucaitis JA, Gage R, Orr T, Shuber AP and Ross ME: Sensitivity and specificity of a stool DNA multitarget assay panel for the detection of advanced colorectal neoplasia. Clin Colorectal Cancer 3: 47-53, 2003.

15. Imperiale TF, Ransohoff DF, Itzkowitz SH, Turnbull BA Ross ME and Colorectal Cancer Study Group: Fecal DNA versus fecal occult blood for colorectal-cancer screening in an average-risk population. N Engl J Med 351: 2704-2714, 2004.

16. Diehl F, Schmidt K, Durkee KH, et al: Analysis of mutations in DNA isolated from plasma and stool of colorectal cancer patients. Gastroenterology 135: 489-498, 2008.

17. Song K, Fendrick AM and Ladabaum U: Fecal DNA testing compared with conventional colorectal cancer screening methods: a decision analysis. Gastroenterology 126: 1270-1279, 2004.

18. Woolf SH: A smarter strategy? Reflections on fecal DNA screening for colorectal cancer. N Engl J Med 351: 2755-2758, 2004.

19. Brenner DE and Rennert G: Fecal DNA biomarkers for the detection of colorectal neoplasia: Attractive, but is it feasible? J Natl Cancer Inst 97: 1107-1109, 2005.

20. Loktionov A: Cell exfoliation in the human colon: Myth, reality and implications for colorectal cancer screening. Int J Cancer 120: 2281-2289, 2007.

21. Villa E, Dugani A, Rebecchi AM, et al: Identification of subjects at risk for colorectal carcinoma through a test based on K-ras determination in the stool. Gastroenterology 110: 1346-1353, 1996.

22. Loktionov A, O'Neill IK, Silvester KR, Cummings JH, Middleton SJ and Miller R: Quantitation of DNA from exfoliated colonocytes isolated from human stool surface as a novel noninvasive screening test for colorectal cancer. Clin Cancer Res 4: 337-342, 1998.

23. Ahlquist DA, Harrington JJ, Burgart LJ and Roche PC: Morphometric analysis of the 'mucocellular layer' overlying colorectal cancer and normal mucosa: relevance to exfoliation and stool screening. Hum Pathol 31: 51-57, 2000.

24. Bedi A, Pasricha PJ, Akhtar AJ, et al: Inhibition of apoptosis during development of colorectal cancer. Cancer Res 55: 1811-1816, 1995

25. Graeber TG, Osmanian C, Jacks T, Housman DE, Koch CJ, Lowe SW and Giaccia AJ: Hypoxia-mediated selection of cells with diminished apoptotic potential in solid tumors. Nature 379: 88-91, 1996.

26. Jass JR, Whitehall VL, Young J and Leggett BA: Emerging concepts in colorectal neoplasia. Gastroenterology 123: 862-876, 2002 .

27. Itzkowitz SH, Present DH and Colitis Foundation of America Colon Cancer in IBD Study Group: Consensus conference: Colorectal cancer screening and surveillance in inflammatory bowel disease. Inflamm Bowel Dis 11: 314-321, 2005.

28. Loktionov A, Bandaletova T, Llewelyn AH, Ferrett CG, Lywood RCG and Lywood HGG: Colorectal cell sampling device. World Intellectual Property Organisation. International Publication Number WO 2006/003447 A1, 2006.

29. Klaassen CHW, Jeunink MAF, Prinsen CFM, Ruers TJ, Tan AC Strobbe LJ and Thunnissen FB: Quantification of human DNA in feces as a diagnostic test for the presence of colorectal cancer. Clin Chem 49: 1185-1187, 2003.

30. Van Lieshout EMM, Van Doesburg W and Wan der Meer R: Real-time PCR of host DNA in feces to study differential exfoliation of colonocytes between rats and humans. Scand J Gastroenterol 39: 852-857, 2004.

31. Bland M: An introduction to medical statistics. Oxford Univ. Press, Oxford, New York, pp277-278, 2000.

32. Whitney D, Skoletsky J, Moore K, et al: Enhanced retrieval of DNA from human fecal samples results in improved performance of colorectal cancer screening test. J Mol Diagn 6: 386-395, 2004.

33. Olson J, Whitney DH, Durkee K and Shuber AP: DNA stabilization is critical for maximum performance of fecal DNAbased colorectal cancer tests. Diagn Mol Pathol 14: 183-191, 2005.

34. Morikawa T, Kato J, Yamaji Y, Wada R, Mitsushima T and Shiratori Y: A comparison of the immunochemical fecal occult blood test and total colonoscopy in the asymptomatic population. Gastroenterology 129: 422-428, 2005. 